\title{
Studies on trematode parasites of air breathing fishes of Awangsoi Lake, Manipur
}

\section{H. Puinyabati ${ }^{1}, M$. Shomorendra² and Devashish K ar ${ }^{1 *}$}

${ }^{1}$ Division of Wetlands, Fishery Science and Aquaculture, Department of Life Sciences, Assam (Central) University, Silchar-11, INDIA

${ }^{2}$ Fish Disease Research Lab., Department of Zoology, Thambal Marik College, Oinam-795134 (Manipur), INDIA

*Corresponding author. E-mail: devashishkar@yahoo.com

Abstract: The present investigation deals with a systematic survey of trematode parasites of air breathing fishes from Awangsoi Lake collected during 2008-2009. The air breathing fishes found in Awangsoi Lake are Channa punctatus, Clarias batrachus, Channa striatus, Channa orientalis, Anabas testudineus and $\mathrm{H}$ eteropneustes fossilis. During the study period the following 5 species of trematodes were collected : Clinostomum complanatum, Allocreadium handia, Allocreadium fasciatusi, Astiotrema reniferum and Genarcopsis goppo. The percentage of abundance was found to be maximum in Astiotrema reniferum and Anabas testudineus harbours the maximum number of parasites.

K eywords: Trematode, Air breathing fishes, Awangsoi Lake, Manipur

\section{INTRODUCTION}

Fish is a vital source of human food particularly in terms of high quality proteins. For the people of Easter India in general and North East India in particular fishes constitude a major component of diet. With the increasing demand for fish, practice of pisciculture has been intensified. Consequently, pisciculturist have been facing various hazards. One among such hazards is the diseases resulting from parasitic infections. The present study aims at determining the trematode parasites of air breathing fishes from Awangsoi Lake, Manipur, which will further contribute to our understanding of helminth community diversity.

Work of Yamaguti $(1958,1959,1961,1962$ and 1963) related to occurrence of helminth parasites in vertebrate host is of immense importance. Further Chubb (1979, 1980) illustrated the studies of seasonal occurance of helminths in fresh water fishes in different climate zones of the world. Considerable work has been done on the systematics of monogenetic trematodes of fishes by many Indian workers. Many workers like Bhalerao (1942), Dayal (1949), Gupta (1951), Srivastava (1960), made substantial contribution to the taxonomy of digenetic trematode parasites. Kar and Sen (2007) studied on systematic list and distribution of fish biodiversity in Mizoram, Tripura and Barak drainage in North East India. Kar et al. (2008) studied on the panorama of fish diversity in certain rivers, wetlands and protected areas in Assam. Kar and Barbhuiya (2009) studied on the Mahseer fishes of Barak
Drainage, Mizoram and Tripura. Barbhuiya et al. (2009) worked on fish biodiversity in certain rivers of Tripura. Shomorendra and Jha (2003) reported a new nematode parasite Paraquimperia manipurensis n.sp. from the intestine of Anabas testudineus. The present study deals with a systematic summary and abundance of treamendous parasites of air breathing tissues from Awangsoi Lake, Manipur.

\section{MATERIALS AND METHODS}

Awangsoi Lake is located to the south of Keinou village in Bishnupur District about $22 \mathrm{~km}$. from Imphal. It has an area of about 100 ha. and a depth of about 2.5 meters. Fishes were collected alive almost every alternate day from the fishing sites and brought to the laboratory in the polythene bags containing water of the same locality. Small fishes were killed by pithing and somewhat larger specimens by blow on the top of the cranium. The external body surface as well as the internal body organs were thoroughly examined for the parasites. The trematodes were fixed in AFA (alcohol-formalin-acetic-acid) solution and stored in $70 \%$ alcohol. To facilitate identification of the worms the trematodes were stained in alum carmine and mounted in Canada balsam.

\section{RESULTS AND DISCUSSION}

The results of the present study are given in Table 1. A rich diversity of about 40 species of fishes have been recorded from the study site. The knowledge of the trematode fauna of the air breathing fishes along the 
Table 1. Host parasite list showing percentage of abundance of parasites, (+) indicates presence of parasites, (-) indicates absence of parasite.

\begin{tabular}{|c|c|c|c|c|c|c|c|c|c|}
\hline \multirow{2}{*}{$\begin{array}{l}\text { S. } \\
\text { No. }\end{array}$} & \multirow{2}{*}{$\begin{array}{l}\text { Name of } \\
\text { parasite }\end{array}$} & \multicolumn{6}{|c|}{ Name of fish host } & \multirow{2}{*}{$\begin{array}{c}\text { Total } \\
\text { no. of } \\
\text { parasite } \\
\text { found }\end{array}$} & \multirow{2}{*}{$\begin{array}{c}\% \\
\text { abundance }\end{array}$} \\
\hline & & $\begin{array}{l}\text { Channa } \\
\text { punctatus }\end{array}$ & $\begin{array}{c}\text { Channa } \\
\text { orientalis }\end{array}$ & $\begin{array}{l}\text { Channa } \\
\text { striatus }\end{array}$ & $\begin{array}{l}\text { Anabas } \\
\text { testudineus }\end{array}$ & $\begin{array}{l}\text { H eteropneustes } \\
\text { fossilis }\end{array}$ & $\begin{array}{c}\text { Clarias } \\
\text { batrachus }\end{array}$ & & \\
\hline 1 & $\begin{array}{l}\text { Clinostomum } \\
\text { complanatum }\end{array}$ & $+(71)$ & - & - & - & - & - & 71 & 18.58 \\
\hline 2 & $\begin{array}{l}\text { Allocreadium } \\
\text { handia }\end{array}$ & $+(19)$ & $+(33)$ & - & - & - & - & 52 & 13.61 \\
\hline 3 & $\begin{array}{l}\text { Allocreadium } \\
\text { fasciatusi }\end{array}$ & $+(15)$ & $+(13)$ & - & - & - & - & 28 & 7.32 \\
\hline 4 & $\begin{array}{l}\text { Astiotrema } \\
\text { reniferum }\end{array}$ & - & - & - & $+(104)$ & $+(86)$ & $+(12)$ & 202 & 52.87 \\
\hline 5 & $\begin{array}{c}\text { Genarcopsis } \\
\text { goppo }\end{array}$ & $+(15)$ & - & - & - & $+(14)$ & - & 29 & 7.59 \\
\hline
\end{tabular}

study site is recent. Almost all the air breathing fishes studied were infected with one or more species of trematode parasites. Clinostomum complanatum was found to infect the liver of Channa punctatus. Allocreadium handia and Allocreadium fasciatusi were collected from the intestine of Channa orientalis and Anabas testudineus. Astiotrema reniferum was found to infect the liver of Anabas testudineus and also in the intestine of $\mathrm{H}$ eteropneustes fossilis and Clarias batrachus. Channa punctatus and Heteropneustes fossilis were also infected by Genarcopsis goppo. The percentage of abundance was found to be maximum $(52.87$ $\%)$ in Astiotrema reniferum and minimum (7.32 \%) in Allocreadium fasciatusi. Clarias batrachus and A nabas testudineus harbours the minimum (1) species of trematode while Channa punctatus harbours the maximum(4).

Diseases affect the normal health conditions and cause and reduction of growth, abnormal metabolic activities and even death, thus results great economic loss. Healthy of a population depends on the control of diseases and maintenance of a healthy relationship between living creatures and their environment (Snieszko, 1983). Five factors directly influence the parasite fauna of fishes like age, diet, abundance of fishes, independent number of a parasite within fish and season (Kabata, 1985). Srivastava (1975) stated that the characteristic of any water body can influence and determine its parasitic fauna and when environmental conditions such as water, food and temperature become flavourable for mass reproduction of parasites, the disease may spread very quikly.

\section{ACKNOWLEDGEMENTS}

The authors are thankful to the Director, ZSI, Kolkata; Principal, Thambal Marik College, Oinam for giving laboratory facilities. Thanks are due to Shri S.R. Dey Sarkar and Dr. S.B. Bhatacharya of ZSI, for identifying the specimens and to UGC, New Delhi for granting UGCfellowship to the first author.

\section{REFERENCES}

Barbhuiya, A.H., Das, B., Darlong, L., Tarafdar, R.G., Sharma, R., Sharma, S.S., Datta, S., Das, B., Barman, R., Deb, S., Saha, B., Kar, D. (2009). Fish Biodiversity in certain rivers of Tripura. Environment and E cology, 27(1): 222-227.

Bhalerao, G.D. (1942). Some metacercarial forms of Clinostomadae (Trematoda) from India, Proc. Indian A cad. Sci., 67-71. Sect. B, 16:3.

Bray, R. A. (1987). A revision of the FamilyZoogonidae Odhner, 1902 (Platyhelminthes: Digenea): subfamily Lepidophyllinae and comments on some aspects of biology. Systematic Parasitology, 9: 83-123.

Chubb. J.C. (1979). Seasonal occurrence of helminth in freshwater fishes, part-I, Monogenia. Advances in Parasitology, 15: 133-199.

Chubb, J.C. (1980). Seasonal occurrence of helminth in freshwater fishes. Part-II.Trematoda. Advances in Parasitology, 17: 171-313.

Dayal, J. (1949). Trematode parasites of Indian fishes-II. Indian J. Hel minth., I (2):93-116.

Gupta, S.P. (1951) On a new trematode, Phyllodistomum singhiai_n. sp. of the family of Gorgoderidae looss 1899 from the intestine of a freshwater fish Mastacambellus ar matus (Lacep) . Indian J. Helminth, 3(1):21-28.

Kabata (1985). Parasites and diseases of fish cultured in the tropics. Taylore and Francis Ltd., London, 318 pp.

Kar, D. and Sen, N. (2007). Systematic list and distribution of fish biodiversity in Mizoram, Tripura and Barak drainage in North East India. Zoos Print J ournal, 22(3): 2599-2607.

Kar, D., Barbhuiya, A.H., Baruah, A.R., Choudhury, C., Banerjee, P., Paul, K., Bhatacharjee, A., Saikia,R., Dar, B. Barman, R. and Saha, B.(2008). Panorama of fish diversity in certain rivers, wetlands and protected areas in Assam, Geobios, 36:57-64.

Kar, D. and Barbhuiya, A.H. (2009). Mahseer fishes of Barak Drainage, Mizoram and Tripura, Souvenir: National Symposium on Coldwater Fisheries Management: New Strategies and Approaches, 2-4 Oct. 09, Directorate of Coldwater Fisheries Research (ICAR), Bhimtal, 
Uttarakhand, India: pp.77-80.

Srivastava, P.S. (1960). On a new trematode Allocreadium ophiocephalus n. sp. Ophiocephalidae. Indian J. H elminth, 12(2):108-113.

Srivastava, C.B. (1975). Fish pathological studies in India: A brief review. Dr. B.S. Chouhan Comm. pp 649-358.

Shomorendra, M. and Jha, A.N. (2003). On a new nematode parasite $P$ araquimperia manipurensis n.sp. from the intestine of Anabas testudineus (Bloch). U ttar Pradesh J. Zool., 23(2):155-157.

Yamaguti, S. (1958). Systema Helminthum Vol. 1. The digenetic trematodes of verteb-rates, Intersciece, New York. Druzno lake-Part-I, Acta Parasite Pole., 6:1-64.

Yamaguti. S. (1959). Systema Helminthum Vol. II. The Cestoda of vertebrates. Inter-Sciences, New York.

Yamaguti, S.(1961). Systema Helminthum Vol-III .The Nematode Vertebrates Part I and II. Interscience Publisher,pp.1-1261.

Yamaguti, S. (1962). Systema Helminthum Vol. III. The nematodes of vertebrates, invertebrates, Inter-Science, New York. Yamaguti, S. (1963). Systema Helminthum Vol. V. Acanthocephala, Inter-Science, New York. 